\title{
The Politics of Agricultural Policy - A Reply
}

\author{
Robert Bates
}

One purpose of this note is to reply to Manfred Bienefeld's critique. Another and more interesting objective is to generate from the discussion a list of topics for further investigation. Regrettably, this reply to Bienefeld's critique must be hurried and tentative - hurried because I postponed writing it while awaiting his final draft; tentative because the final draft failed to appear in time for me to employ it. I am therefore reacting to notes which he prepared for his lecture, trusting that his final position will not change significantly from the time of his presentation.

\section{Counter-arguments}

Bienefeld's basic position would appear to contain three major points:

i) The basic parameters for Africa's development are set by international market conditions. Domestic policy choices are relatively unimportant in consequence.

ii) Prices - certainly international prices - provide a misleading guide to allocational decisions.

iii) Governments should therefore seek to alter the allocations which would result from the use of (international) market prices.

It is impossible to reply at length to these points. Instead I shall touch upon them only insofar as they provide the grounds for Bienefeld's criticism of my work. Moreover, given the limitations on my time, I shall have to debate them in a light and I fear, somewhat, unscholarly manner, foreswearing the usual impedimenta of scholarly controversy: references, citations, supporting evidence, and such.

My strategy will be to take points i) and ii) singly. Point iii) will be attacked by undermining the first two, from which it is deduced.

\section{Are Parameters Set by the World Market?}

In discussing my work, Bienefeld repeatedly stresses that the contemporary condition of African economies demonstrates the determining influence of international economic conditions upon their economic performance. I am held to be 'writing in the 1980s' and I should therefore have known better than to place primary stress on the policy choices of African governments.

Although read by Bienefeld in the 1980 s, I was in fact writing in the 1970s. While the oil price rise of the 1970s hurt many African nations, it favoured others; the oil exporting nations comprised approximately one quarter of sub-Saharan Africa's population. The oil-importing nations experienced commodity booms of their own. I refer to price movements in the market for coffee which, next to oil, is the most valuable commodity exchanged in international markets. There were, of course, grievous problems in international trade in the 1970 s. But they were simply not of the same magnitude as those witnessed at present.

My major point, however, is that I feel it unwise to insist, as Bienefeld does, on the distinction between politics (especially domestic politics) and markets (specifically, international markets). The division disguises the degree to which there is a political dimension to the way in which Third World nations incorporate themselves into international markets. Not all nations employ the same strategy; a given nation, over time, may employ a variety of strategies. There is a range of discretion and choice about the way in which domestic political economies can be coupled to international markets. And understanding what determines the policy choices which lead to different forms of incorporation represents an important section of the research frontier in development studies.

An appropriate illustration is furnished by the International Coffee Agreement, which places quantity constraints on coffee exports in an effort to secure higher international prices. Some nations adjust to these constraints by over-valuing their currencies. One result, at current world prices, is the reduction of

WDS Bufletin. 1986. vol 17 no 1, Institute of Development Studies, Sussex 
exports; another is the redistribution of economic opportunities from exporters to importers. Other nations adjust by limiting production; this measure favours established producers and penalises new entrants. Other nations adjust by taxing exports; still others by purchasing all that is produced while limiting exports by accumulating inventories. These measures represent contrasting transfers between producers and the fisc. Confronted with a single stimulus originating from the international marketplace, then, governments assign the costs of adjustment to different domestic groupings. These contrasting policies represent a variety of political accommodations to the international market.

The point is that rigidly distinguishing between international markets and domestic politics is relatively uninformative. A range of choices exists and the particular strategy chosen determines the magnitude and distribution of the costs of adjustment. This realisation encourages as well the adoption of a perspective which focuses on the relative merits of different strategies. Given that governments can make policy choices but cannot control international markets, it focuses attention on issues which can be determined by action. In this sense, pace Bienefeld, the approach may in fact be more oriented toward 'the real world'.

It may be useful to point out as well that the distinction between domestic politics and international markets lacks utility when applied to that portion of the market which is external to the African economies. One need but observe the impact of the domestic policies of the United States upon international market prices, both for commodities and capital. The stockpiling of strategic materials in the 1950 s drove up commodity prices; so too did the decision to finance the Vietnam war without cutting back domestic spending. The impact of domestic politics is further illustrated by the current budgetary crisis, which has driven up interest rates in international capital markets, with grievous implications for the financing of Third World debt. Were Bienefeld to counter by arguing that the United States is so sheltered from world market forces as to discredit an approach that requires that it be analysed in the same terms as the dependent political economies of Africa, I would then invite him to talk with those who have lost their jobs as a consequence of the decisions taken by their 'policy makers' - job losses which resulted from the impact of fiscal deficits on the competitiveness of export industries. I would also invite him to analyse the impact of the necessity to maintain international competitiveness upon the domestic political sustainability of social welfare programmes in advanced industrial nations. It is arguable that social democracy in the developed world is yet another victim of the mobility of economic resources in international market environments.

\section{Prices: A Good Guide to Decisions?}

Point ii): I employed pricing data to analyse politics. 'Market' prices provided a benchmark. I attempted to use them to determine what would have prevailed in the absence of government market intervention, and then to infer whose interests prevailed in the attempts by interests to manipulate pricing policies. I attempted not only to analyse the way in which market interventions are employed for political purposes, but also the manner in which they generate political resources - resources which would be used to organise.

In using 'market' prices as a methodological reference point, I made no commitment to them as being inherently more moral or just. I do in fact feel that given the distribution of income in most African societies in the 1970s, market prices were to be preferred to those which governments sought to implement. But that does not imply a generalised commitment to the market as an allocational institution.

Insofar as Bienefeld infers such a generalised commitment, then, he is mistaking my methodological position for an ethical commitment. But Bienefeld goes beyond ethics to considerations of efficiency. $\mathrm{He}$ makes the point that market signals - i.e. prices often provide information which is misleading, in the sense that it leads to an inefficient allocation of resources. This is particularly the case, he argues, with dynamic allocational programmes, given the level of uncertainty inherent in intertemporal choice. The inference he draws is that governments should override the market for purposes of 'long-run efficiency'.

A basic problem with Bienefeld's argument is that it is insufficiently elaborated. Capital markets - the markets in which intertemporal allocations are secured - could be inefficient because they are noncompetitive. A proper response would then be the encouragement of more private sector lending rather than less, as by relaxing barriers to entry. Or capital markets may be inefficient because they are incomplete; public guarantees for new forms of contracts (or contingent claims) could then be the remedy - contracts which are then tradeable in private markets. The point is that to go from the existence of market failure to the prescription of the remedy of government investment is to make far too grand a leap. 
There is a second major portion of Bienefeld's discussion of efficiency - a portion which directly addresses the subject of my work, which was African agriculture. Governments, Bienefeld argues, tax agriculture in order to induce development, and that is a basic reason for their pricing policies. The departure of official prices from market prices is therefore in keeping with the 'transformational' (my word, not Bienefeld's) role of government and the goal of 'long term efficiency' (Bienefeld's word, not mine). This conclusion is reached by noting that taxes constitute a major source of price distortions in export agriculture; that agriculture constitutes a major portion of the tax base and agricultural exports generate a major portion of the foreign exchange earnings in most African countries; and that governments need revenues and foreign exchange in order to invest in development projects.

It is important to realise that Bienefeld's conclusion about governmenta! pricing policies does not follow from the initial conditions. Quite simply, there are ways of taxing agriculture other than by taxing the commodities produced by farmers: income taxes, sales taxes, or land taxes, for example. The significance of these alternatives is that were they used, they would induce a governmental preference for higher agricultural prices; higher prices would result in higher profits for farms and therefore greater revenue collections from the incomes or consumption purchases of farm families or from the increased value of their land. The 'low price' policies of African governments thus do not inevitably result from their need for taxes; rather, they may result from the specific nature of the fiscal instruments at their command.

Not only are there many ways to tax. There are also many ways of moving resources out of agriculture - which many take to be the hallmark of 'development' - other than by taxing it. Increased farm productivity, given inelastic demand, would lead to a shift of land, labour, or capital from farming, all else being constant. The 'Mills/Marshall treadmill' has lead to the structural transformation of economies elsewhere in the world. An important part of Bienefeld's position, then, is not elaborated. It has to do with why he would find it preferable to secure the 'great transformation' through the fiscal system of the state rather than through market competition.

A likely possibility, of course, is that Bienefeld would find the social costs of this alternative too great, the major such cost being the magnitude and kind of the resultant inequality. But then many find the social costs of the state-led alternative high, given the kind and magnitude of inequality which it produces. The major point is that debates concerning equality are not likely to resolve the controversy concerning the two transformational strategies, for in terms of their impact on equality, there may be little to choose between them.

Let us assume that Bienefeld meets all of these objections. That is, let us assume that we have in fact conceded that market systems are inefficient and socially undesirable; that they promote decisions which lead to insufficient investment; and that governments must therefore provide the primary source of investment and secure resources from agriculture. The question then arises: Why, under these circumstances, would one feel that the government would do a particularly good job of investing? Are public employees smarter? Certainly my abilities do not rise when I draw my pay from a development agency rather than from my university; nor do I find those for whom I consult to be smarter than my colleagues in private life. Or is it that governments are better motivated - e.g. rather than focusing on short-run profits, they take a more "far sighted' point of view or, rather than looking at private profits, they instead focus on the 'social interest?' The first position is palpably false. The United States government is now outcompeting private borrowers in its desire to finance present spending; and the pressures of electoral competition and the fear of coups generate strong incentives for Third World governments to generate present benefits. (In many African nations, it should be noted, the recurrent budget has displaced capital spending.) The second position is indecisive. It turns on an unresolved debate: whose version of the social interest shall guide investment choices? The reference point for government decision-making remains undermined and the approach is therefore useless as a guide to government behaviour.

Having given so much of the action to governments, Bienefeld cannot convince us that they will in fact act in the way they must if his position is to be persuasive. Even more to the point, he lacks a theory of how they will - as opposed to how they should - behave. His position has no politics.

\section{Should Governments Alter Market Allocation?}

Point iii) follows from points i) and ii). As an independent argument, it may or may not be valid. I lack the time and space to address its independent merits. But insofar as its validity derives from the validity of its premises, it clearly is deeply flawed.

\section{Implications}

Where, then, does this discussion lead? Clearly, both for Bienefeld's position and my own, there is a need for the study of domestic policy formation. Why do 
governments get involved in their economies the way they do? Why do they choose to intervene and what determines the manner and pattern of their interventions?

In analysing government behaviour, the discussion suggests, we would do well to choose subjects which avoid polarising the analysis between advocacy of the market and defence of the public sector. Political involvement is a fact of life; given that, it should be analysed. One way of proceeding is by comparing and contrasting the ways in which different governments intervene in the same arenas; the passage from description to explanation can then be achieved by trying to account for the variations in their behaviour. An example would be the study of patterns of market intervention in agriculture. Another would be a comparative study of marketing boards, noting the way in which different boards regulate the production, processing, and sale of different commodities. Such studies would allow us to analyse governmental behaviour and to advocate ways in which the conduct of public agencies could be improved.

The discussion indicates that a second key set of studies should focus on the variety of ways in which governments accommodate international markets. Why do some countries adopt 'outward oriented' strategies while others attempt to shelter themselves from foreign markets? Why do some countries adopt overvalued currencies while others seek to maintain 'open market' valuations? What accounts for the transition between different trade strategies? Are there systematic differences between the coalitional basis for different policy regimes? How is the transition from one regime to another politically managed?

It should be noted that several critical subjects for study fall into this last category. One would be the study of commodity agreements: why do some governments invest in the diplomacy necessary to achieve these whereas others choose to remain as price takers in international markets? Another would be the politics of structural adjustment - of the domestic and diplomatic dynamics which underlie political relations with international capital markets. A third would be the study of the political role of 'economic technocrats'. How and under what circumstances do they become politically influential? How and under what circumstances do they achieve the power to override 'spending ministries' and seize the power of policy formation? What role do they play in leading governments to adopt 'market conforming' policies?

There remains a last major topic - one also designed to capitalise on the admixture of such divergent positions as Bienefeld's and my own. Insofar as governments seek to regulate markets, parallel markets will form. The existence of government as an actor in the marketplace surely conditions the nature of private economic activity. In what ways does it do so? And the existence of parallel, private markets surely conditions the behaviour of public agencies and alters the way in which policy instruments link to the attainment of public objectives. In what ways does the existence of parallel markets alter the behaviour and strategies of public organisations? Much of Africa's economic activity takes place in parallel markets. But these markets remain unstudied through empirical investigation and unanalysed through the application of formal methods of economic reasoning. Their analysis has not gone much further than arguing whether private markets are a good thing or bad. More important is the acquisition of knowledge. We need to know their impact upon the nature of the private economy (i.e. on the rise of 'African capitalism') and their implication for the behaviour of public agencies (i.e. on the development of the African state).

The 'public versus private' debate represents the least interesting portion of political economy. It certainly is among the least productive, and its continuation will frustrate progress. Rather, we should be analysing the origins of governmental involvement, the manner of these involvements, and the nature of their impact. Economists can no longer pretend there is no government; nor can they leave it as a 'black box'; nor can they fill in the black box by endowing governments with the ability and intention to perform the tasks which they believe must be performed to secure development. Rather, given that governments are major allocational agencies in their own right, and that they influence as well the value of allocations made outside of the public arena, economists should take governments as objects of study and attempt seriously to comprehend the determinants of their behaviour. 